\title{
Study of ash deposition during coal combustion under oxyfuel conditions
}

\author{
L. Fryda ${ }^{\mathrm{a}, *}$, C. Sobrino ${ }^{\mathrm{b}, 1}$, M. Glazer $^{\mathrm{b}}$, C. Bertrand ${ }^{\mathrm{a}}$, M. Cieplik ${ }^{\mathrm{a}} \equiv$ \\ ${ }^{a}$ Energy Research Centre of the Netherlands (ECN), Westerduinweg 3, 1755 LE Petten, The Netherlands \\ ${ }^{\mathrm{b}}$ Process and Energy Department, Faculty of Mechanical, Maritime and Materials Engineering, Delft University of Technology, The Netherlands
}

\begin{abstract}
A B S T R A C T
This paper presents a comparative study on ash deposition of two selected coals, Russian coal and lignite, under oxyfuel $\left(\mathrm{O}_{2} / \mathrm{CO}_{2}\right)$ and air combustion conditions. The comparison is based on experimental results and subsequent evaluation of the data and observed trends. Deposited as well as remaining filter ash (fine ash) samples were subjected to XRD and ICP analyses in order to study the chemical composition and mineral transformations undergone in the ash under the combustion conditions. The experimental results show higher deposition propensities under oxyfuel conditions; the possible reasons for this are investigated by analyzing the parameters affecting the ash deposition phenomena. Particle size seems to be larger for the Russian coal oxy fired ash, leading to increased impaction on the deposition surfaces. The chemical and mineralogical compositions do not seem to differ significantly between air and oxyfuel conditions.

The differences in the physical properties of the flue gas between air combustion and oxyfuel combus tion, e.g. density, viscosity, molar heat capacity, lead to changes in the flow field (velocities, particle tra jectory and temperature) that together with the ash particle size shift seem to play a role in the observed ash deposition phenomena.
\end{abstract}

\section{Introduction and scope of work}

Combustion in $\mathrm{O}_{2} / \mathrm{CO}_{2}$ mixture (oxyfuel) has been recognized as a promising technology for $\mathrm{CO}_{2}$ capture as it produces flue gas with a high $\mathrm{CO}_{2}$ concentration, which can be sequestered and stored [1 8]. The technology consists of combusting the fuel with a blend of oxygen, produced in an Air Separation Unit (ASU), and recircu lated flue gas. In theory, it is possible to retrofit existing air blown pulverized fuel (PF) units in order to enable oxyfuel combustion. However, key issues such as equivalent heat transfer between air and oxyfuel operation, ash formation and deposition, flue gas cleaning prior to recycling or storage and burner adjustments still need to be further investigated prior to the commercialization of the technology. In this frame, targeted lab scale tests and advanced modeling are cost effective and relatively fast tools to gain insight and knowledge on specific operation parameters. This approach al lows testing a wide variety of fuels in a consistent range of com bustion conditions, while at the pilot scale level technical issues relative to the whole plant operation are confronted.

The objective of this work is the comparative study of ash for mation and deposition of two coals fired under oxyfuel and air con ditions in a lab scale pulverized fuel combustor.

\footnotetext{
* Corresponding author. Tel.: +31224564641.

E-mail address: fryda@ecn.nl (L. Fryda).

1 Present address: Departamento de Ingeniería Térmica y de Fluidos, Universidad Carlos III de Madrid, Spain.
}

An overview of research activities and technology develop ments on oxyfuel combustion including char combustion temper atures, fuel burnout, gas composition, heat transfer, coal reactivity and flame ignition has been published by Wall et al. [9]. The gas environment experienced by pulverized coal particles under oxyfuel combustion is different from the conditions experi enced under standard air combustion, which may impact the com bustion processes including ignition [10,11], combustion characteristics $[5,10,12]$, char reactivity under high $\mathrm{CO}_{2}$ concentra tions $[9,13,14]$, and pollutant formation $[5,12,1518]$. The conse quence of these may become important when the pulverized fuel boilers are planned to be retrofitted to oxyfuel. The higher thermal capacity of $\mathrm{CO}_{2}$ compared to $\mathrm{N}_{2}$, the lower mass diffusivity of $\mathrm{O}_{2}$ in $\mathrm{CO}_{2}$ than in $\mathrm{N}_{2}$, and the endothermic reaction between char and $\mathrm{CO}_{2}$ lowers the char combustion temperature in $\mathrm{O}_{2} / \mathrm{CO}_{2}$ mixtures compared to $\mathrm{O}_{2} / \mathrm{N}_{2}$ mixtures with a same oxygen concentration [19].

Ash formation and ash related behavior depends on the com bustion conditions as well as on coal composition and mineralogy. Understanding of the impact of oxyfuel combustion on the ash behavior has not yet been fully established. Experiments on more coals are required to allow generalization of the results and conclu sions to a wide range of applications. Few studies have been pub lished on ash formation and deposition under oxyfuel combustion [15,19 23]. Sheng et al. [15] and Suriyawong et al. [21] showed that, in comparison with air, the combustion in a $20 \% \mathrm{O}_{2} / 80 \% \mathrm{CO}_{2}$ mixture, shifted the particle size distribution of the submicron 


\begin{tabular}{|c|c|c|c|}
\hline $\begin{array}{l}D P \\
d_{c}\end{array}$ & $\begin{array}{l}\text { deposition propensity } \\
\text { deposition probe diameter }(\mathrm{m})\end{array}$ & $X_{\text {fuel ash }, i}$ & $\begin{array}{l}\text { mass fraction of the element } i \text { (expressed as oxide) in } \\
\text { the fuel ash }\end{array}$ \\
\hline$d_{p}$ & particle diameter $(\mathrm{m})$ & $R_{B / A}$ & ratio of acidic to basic oxides \\
\hline$E F$ & enrichment factor & $R_{f}$ & fouling factor $\left(\mathrm{K} \mathrm{m}^{2} / \mathrm{W}\right)$ \\
\hline$F_{i}$ & fouling index & St & Stokes number \\
\hline ICP & Inductively Coupled Plasma & $t$ & time $(s)$ \\
\hline LCS & Lab Scale Combustion Simulator & $T_{g}$ & flue gas temperature $(\mathrm{K})$ \\
\hline$H F$ & heat flux $\left(\mathrm{W} / \mathrm{m}^{2}\right)$ & $T_{c}$ & coolant medium temperature $(\mathrm{K})$ \\
\hline HHV & Fuel Higher Heating Value $(\mathrm{K} \mathrm{J} / \mathrm{kg})$ & $U$ & heat transfer coefficient $\left(\mathrm{W} / \mathrm{K} \mathrm{m}^{2}\right)$ \\
\hline$m_{\text {dep }}$ & ash mass deposited $(\mathrm{g})$ & $U_{p}$ & particle velocity (m/s) \\
\hline$m_{\text {ash }}$ & ash mass fed by the fuel $(\mathrm{g})$ & $\mu_{\mathrm{g}}$ & gas viscosity $(\mathrm{kg} / \mathrm{s} \mathrm{m})$ \\
\hline XRD & $\mathrm{X}$ ray diffraction & $\rho_{p}$ & particle density $\left(\mathrm{kg} / \mathrm{m}^{3}\right)$ \\
\hline
\end{tabular}

ash to a smaller size and decreased the yield of submicron parti cles. The elemental composition of submicron particles showed also variations. This was attributed to a decrease in the char parti cle combustion temperature. However, the increasing $\mathrm{O}_{2}$ concen tration in the oxyfuel case diminished these differences.

The varying bulk gas composition changes the $\mathrm{CO} / \mathrm{CO}_{2}$ ratio within the char particle, fact that could affect the vaporization of refractory oxides and consequently affect the formation of fine ash particles. Krishnamoorthy et al. [24] showed that an increased amount of $\mathrm{CO}_{2}$ in the bulk gas reduces the rate of formation of sub micron sized ash. It is demonstrated in various publications that the submicron ash generated during coal combustion is mainly the result of mechanisms like vaporization and homogeneous con densation of refractory oxides such as $\mathrm{SiO}_{2}, \mathrm{CaO}, \mathrm{MgO}$ and $\mathrm{Fe}_{2} \mathrm{O}_{3}$ $[25,26]$.

Furthermore, also the phase transformations of coal mineral matter during combustion are influenced by the coal char combus tion temperatures. XRD measurements can thus give insights into the peak intensities of main crystalline species from the ashes formed in $\mathrm{O}_{2} / \mathrm{CO}_{2}$ and $\mathrm{O}_{2} / \mathrm{N}_{2}$ combustion. It is known that the pres ence of iron in the coal ash promotes the mechanisms of slagging in pulverized coal fired furnaces when combined with sulfur in the form of pyrite. The transformations of iron bearing minerals during air fired pulverized coal combustion include pyrite decom posing to pyrrhotite, an intermediate phase that further oxidizes to a molten $\mathrm{FeO}$ FeS phase and then to the stable magnetite and hematite. The intermediate products, including pyrrhotite with the melting point of $1100{ }^{\circ} \mathrm{C}$ and $\mathrm{FeO}$ FeS with the eutectic tem perature of $940{ }^{\circ} \mathrm{C}$, are prone to coalesce with inherent silicates and form glass silicates. Char combustion under $\mathrm{O}_{2} / \mathrm{CO}_{2}$ may lead to higher $\mathrm{CO}$ concentrations than under $\mathrm{O}_{2} / \mathrm{N}_{2}$ combustion, which slows the transformation of pyrite to oxides, thus possibly increas ing the slagging propensity of the ash $[20,27]$.

Finally, deposit sampling tests performed by Mönckert et al. [28] indicate that besides sulfation, carbonization of deposit sur faces occur. The implication of this observation is not clear.

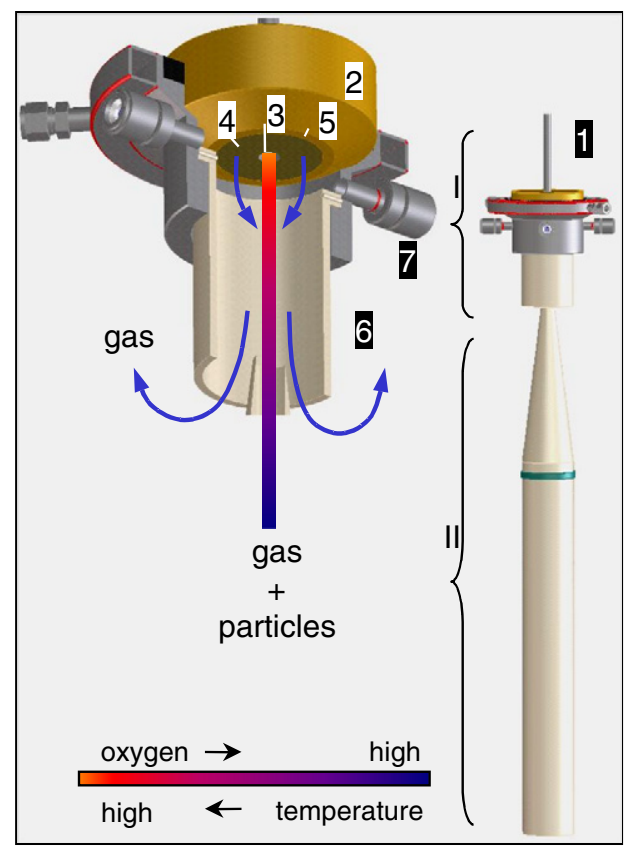

\section{Legend:}

I Devolatilisation zone,

II Combustion zone,

1 Solid fuel feed,

2 Multi-stage flat flame gas burner,

3 Inner burner,

4 Outer burner,

5 Shield gas ring,

6 Reactor tube,

7 Optical access

Fig. 1. Schematic of the ECN's Lab-Scale Combustion Simulator (LCS). 


\section{Description of experimental facility and test procedure}

\subsection{The Lab Scale Combustion Simulator}

The Lab Scale Combustion Simulator (LCS), shown in Fig. 1, developed and optimized by ECN is an advanced, modified drop tube furnace, equipped with a flat flame, multi stage, premixed gas burner, into which the investigated solid pulverized fuel is in jected. This provides adequate heating rates $\left(10^{5} \mathrm{~K} / \mathrm{s}\right)$, in range with full scale PC boilers. The reactor is equipped with a residence chamber with a conical inlet. This causes the flue gas and char/ash particles to decelerate, enabling for long residence times in spite of a relative short length. The char particles are then led into an elec trically heated reactor tube, where they are further combusted. The furnace is $\sim 1.3 \mathrm{~m}$ in length. The burner consists of two concen tric sub burners. The inner burner is supplied with a mixture of $\mathrm{O}_{2}$, $\mathrm{CH}_{4}$, and $\mathrm{CO}_{2}$ or $\mathrm{N}_{2}$ with an oxygen lean rate. In the outer burner the gaseous mixture of $\mathrm{O}_{2}, \mathrm{CH}_{4}$, and $\mathrm{CO}_{2}$ or $\mathrm{N}_{2}$ provides the neces sary oxygen in order to complete the combustion. The total flow of gases was about 30 standard liters per minute (slpm). Fuel parti cles are fed through the inner burner and are rapidly heated to the high temperature level of, e.g., a coal flame (1400 $1600{ }^{\circ} \mathrm{C}$ ). Typically, low particle feed rates of $15 \mathrm{~g} / \mathrm{h}$ are used in order to control the gaseous environment of each particle by means of the imposed gas burner conditions. This implies that heating and dev olatilization of the fuel particles takes place in an oxygen deficient zone (indicated as I in Fig. 1) provided by the primary, inner bur ner, whereas subsequent char combustion takes place in a zone with excess oxygen (indicated as II in Fig. 1). The reactor is sur rounded by three $3.4 \mathrm{~kW}$ furnace sections equipped with Kanthal Super 1800 elements with a maximum element temperature of

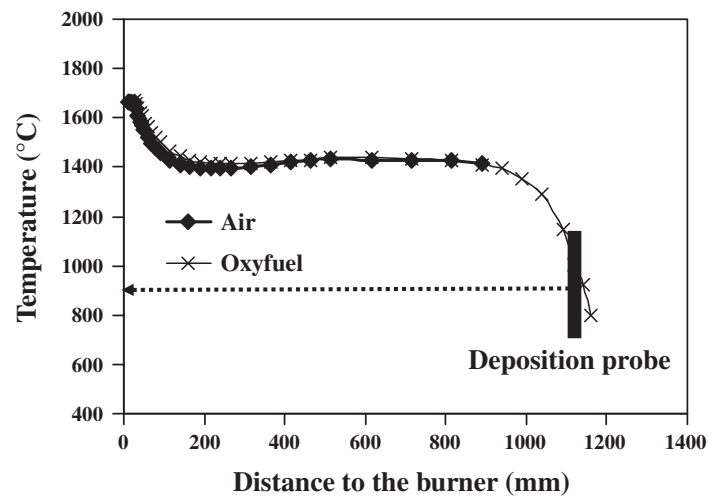

Fig. 2. LCS temperature profiles.

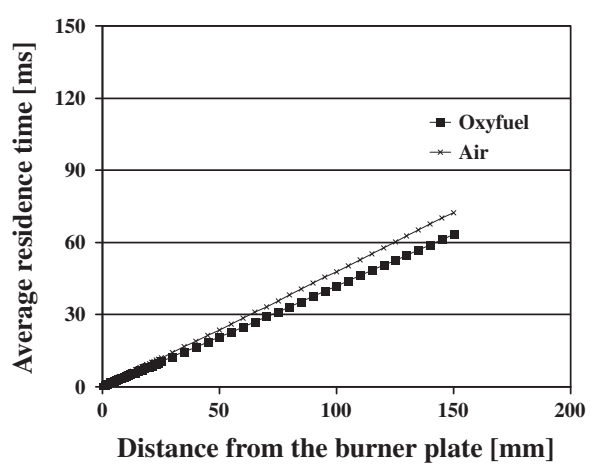

$1700^{\circ} \mathrm{C}$. The furnace temperature profile (Fig. 2) was measured in the absence of the particles, using $S$ type thermocouples. The flue gas composition is continuously monitored using an Ultra Vio let analyzer for $\mathrm{NO}$ and $\mathrm{NO}_{2}$, a NDIR for $\mathrm{CO}$ and $\mathrm{CO}_{2}$ and a magneto mechanical analyzer for $\mathrm{O}_{2}$.

The residence times are shown in Fig. 3, both in the flame area close to the burner plate as well as along the reactor. Residence time calculations are based on the volume flows, the gas velocity, assuming laminar flow and taking into account the reactor geom etry, axial gas temperature profile and the particle terminal veloc ity. The selection of flows was such as to allow for the same residence times in all experiments for the given temperature pro files. A suction pump that operates at a constant volume flow rate also assures for homogeneous velocities and therefore isokinetic conditions in the reactor. Boiler tube fouling studies can be carried out using a horizontal probe placed at $1155 \mathrm{~mm}$ from the burner, simulating the gas/particles flow around a single boiler tube in the convective section of a boiler. It is provided with a ring shaped heat flux sensor installed on the horizontal tube as well as with a detachable tubular deposition substrate. The surface temperature of the probe is controlled by the air cooling system and maintained at $560^{\circ} \mathrm{C}$. When the sensor is used, on line data on the influence of the deposit on the effective heat flux trough the tube wall are col lected. The ash collected on the sensor is taken for ICP/AES analysis. The particles not deposited on the horizontal probe are collected through a vertically adjustable cooled probe at the end of the drop tube reactor on a porous filter and are also analyzed. The carbon in ash levels and particle size distributions were determined for all ash samples.

A series of combustion tests were done dedicated to sampling ash from the filter without using the horizontal deposition probe, thus, without partitioning the produced ash into the sensor and the filter ash.

\subsection{Fuels composition and deposition prediction}

Deposition tests were carried out with the Russian coal and lig nite combusted in $\mathrm{O}_{2} / \mathrm{CO}_{2}$, with a $30 \mathrm{vol}$.\% of oxygen in order to achieve the same adiabatic flame temperature and similar heat transfer characteristics than in air combustion. Proximate (ash, VM and moisture\% (w/w) oven/gravimetry) and ultimate analy ses (C, H, N, O, S Carlo Erba analyzer), as well as inorganic ele mental composition using ICP/AES (29 elements in total) were performed on the fuels, the results shown in Table 1 . The fuels were all ground to less than $500 \mu \mathrm{m}$ in order to be fed in the brush feeder. A series of combustion tests with the coals in air (79 vol.\% $\mathrm{N}_{2}$ and 21 vol.\% $\mathrm{O}_{2}$ ) were carried out as reference as well. Water va por was not included in our tests, as part of the simulated recycled gas input, simulating dry recycling.

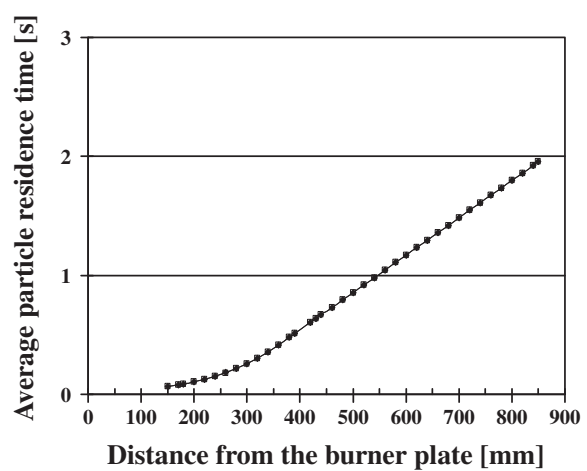

Fig. 3. LCS residence times under air and oxyfuel combustion conditions. 
Table 1

Chemical analysis of the fuels.

\begin{tabular}{lcl}
\hline Fuel & Russian coal & Lignite \\
\hline Moisture & 3.4 & 35.8 \\
Proximate analysis (\% mass, dry fuel basis) & \\
Ash @ $815^{\circ} \mathrm{C}$ & 14.9 & 42.6 \\
Volatile matter & 29.0 & 38.1 \\
$\mathrm{HHV}(\mathrm{K} \mathrm{J} / \mathrm{kg})$ & 27,800 & 13,700 \\
Ultimate analysis (\% mass, dry fuel & basis) & \\
$\mathrm{C}$ & 68 & 33 \\
$\mathrm{H}$ & 4.0 & 2.7 \\
$\mathrm{~N}$ & 0.87 & 0.605 \\
$\mathrm{~S}$ & 0.35 & 0.79 \\
$\mathrm{O}$ by diff. & 11.6 & 18.8 \\
Ash composition (mg/kg fuel, dry & basis) & \\
$\mathrm{Na}$ & 405 & 1600 \\
$\mathrm{Mg}$ & 1277 & 5500 \\
$\mathrm{Al}$ & 16,583 & 34,000 \\
$\mathrm{Si}$ & 34,841 & 64,000 \\
$\mathrm{P}$ & 386 & 110 \\
$\mathrm{~K}$ & 2390 & 6600 \\
$\mathrm{Ca}$ & 2750 & 7100 \\
$\mathrm{Ti}$ & 622 & 1400 \\
$\mathrm{Mn}$ & 89 & 200 \\
$\mathrm{Fe}$ & 6077 & 15,000 \\
$\mathrm{Zn}$ & 21 & 50 \\
$\mathrm{~Pb}$ & 10 & 25 \\
$\mathrm{Sr}$ & 183 & 59 \\
$\mathrm{Cl}$ & 260 & 150 \\
\hline & 100 & 47 \\
\hline & & \\
$\mathrm{Cl}$ & & \\
& &
\end{tabular}

The concentration of the fouling elements like potassium in lig nite is higher than in the Russian coal. Silica content is also higher for the lignite than for the Russian coal.

At this point the fouling index $F_{i}[29,30]$ is introduced for a first assessment of the fouling behavior of the two coals. The fouling in dex is given in Eq. (1) defined as the ratio between alkalis to chlo rine and sulfur in the fuel ash.

$$
F_{i} \frac{(\mathrm{Na}+\mathrm{K})}{(2 \cdot \mathrm{S}+\mathrm{Cl})}
$$

Another index used is the ratio of basic to acidic oxides $R_{B / A}$ (Eq. (2), using the corresponding oxides based on the elemental compo sition) calculated from the fuel ash composition that gives an indi cation about the possible behavior of the tested fuels.

$$
R_{B / A} \frac{\mathrm{Fe}_{2} \mathrm{O}_{3}+\mathrm{CaO}+\mathrm{MgO}+\mathrm{K}_{2} \mathrm{O}+\mathrm{Na}_{2} \mathrm{O}}{\mathrm{SiO}_{2}+\mathrm{Al}_{2} \mathrm{O}_{3}+\mathrm{TiO}_{2}}
$$

The values of the indices are shown in Table 2. Higher values of the $F_{i}$ and the $R_{B / A}$ indicate stronger fouling propensity. Considering the fuels' ash composition, it can be seen from Table 2 that lignite ash is indeed more prone to forming low temperature melting compounds (alkali silicates). The $R_{B / A}$ ratio for the Russian coal is lower indicating the higher share of the alumina silicates within the system. A low value also indicates low concentration of $\mathrm{K} / \mathrm{Na}$ / $\mathrm{Mg} / \mathrm{Ca}$ elements forming basic oxides.

\section{Results and discussion}

\subsection{Fouling factor}

Based on the heat flux data measured on line by the sensor probes the fouling factor $R_{f}$ of the obtained deposits can be esti mated, which corresponds to the heat transfer resistance of the ash deposits:
Table 2

Fouling index $\left(F_{i}\right)$ and ratio of basic to acidic oxides $\left(R_{B / A}\right)$ for the Russian coal and the lignite.

\begin{tabular}{lll}
\hline & $F_{i}$ & $R_{B / A}$ \\
\hline Russian coal & 0.39 & 0.145 \\
Lignite & 0.51 & 0.246 \\
\hline
\end{tabular}

$R_{f}\left(\begin{array}{ll}\frac{1}{U_{1}} & \frac{1}{U_{0}}\end{array}\right) \quad \frac{T_{g} T_{c}^{1}}{H F_{1}} \quad \frac{T_{g} T_{c}^{0}}{H F_{0}}$

where $R_{f}$ is the fouling factor in $\left(\mathrm{K} \mathrm{m}^{2}\right) / \mathrm{W}, U$ is the ash deposits heat transfer coefficient in $\mathrm{W} /\left(\mathrm{K} \mathrm{m}^{2}\right), T_{g}$ is the flue gas temperature in $\mathrm{K}$, $T_{c}$ is the coolant medium temperature inside the deposition probe in $\mathrm{K}$ and $H F$ is the heat flux to the sensor in $\mathrm{W} / \mathrm{m}^{2}$. Subindex 1 refers to the conditions after time $t=t_{1}$, while subindex 0 refers to the ini tial conditions $t=t_{0}=0$.

The fouling factors of the Russian coal and the lignite are de picted in Fig. 4 as an almost linear function of the cumulative ash feed rate. The slopes of the curves plotted become independent of the fuels' various ash contents. The point at which fuel feeding started was considered as the beginning of the heat flux measure ment. In all cases the heat flux, surface temperatures, cooling air flow rate and furnace temperatures reached steady state by the start of the deposition measurement.

Concerning the fuels' deposition behavior under the same com bustion conditions, the trend of the fouling factors shown in Fig. 4 seems contradictory to the fouling indices shown in Table 2. The lignite presents lower fouling factors than the Russian coal even though the fouling index of lignite and the total amount of ash deposited collected during the lignite experiments were higher, as will be also shown in the following section, where the deposi tion propensities for the different tests are calculated. This is be lieved to be due to a higher effective thermal conductivity of the lignite ash, which is strongly influenced by the deposit physical structure, i.e. the particle size distribution, the porosity and the sintering conditions [31]. Chemical composition was found to have little effect on the thermal conductivity, apart from influencing the extent of sintering [32].

When comparing results for the same fuel under different com bustion environments, higher fouling factors are measured in oxy fuel, being this in accordance with a higher amount of ash deposited. The difference between air/oxyfuel fouling factors seems to be due to non chemical parameters, such as fluid dynam ics, char combustion temperatures or ash particle size.

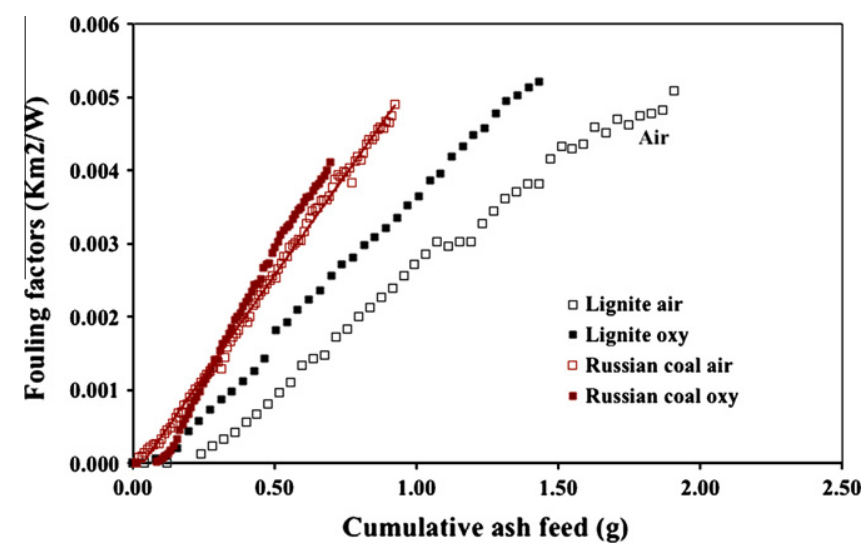

Fig. 4. Fouling factors for the lignite and the Russian coal under air and oxyfuel combustion conditions. (For interpretation of the references to colour in this figure legend, the reader is referred to the web version of this article.) 


\subsection{Deposition propensity}

The ash samples collected in the horizontal probe and in the fil ter during the deposition experiments were weighed. The ash mass balance (percentage of the fuel ash that was collected either in the horizontal probe or the filter during a deposition experiment) was around a $75 \%$ for the all the deposition tests. In order to assess the deposition behavior of the fuel, the deposition propensity DP is introduced, defined as the mass of the ash collected on the deposit probe, $m_{\text {dep }}$, to the mass of the ash in the fuel fed, $m_{a s h}$, calculated using the ash content given in the proximate analysis of the fuel. The deposition propensity provides insight into the inherent depo sition characteristics of the different fuels, as it normalizes the ash deposition in relation with the fuel ash content.

$$
D P \frac{m_{d e p}}{m_{a s h}}
$$

Fig. 5 shows the deposition propensity as defined for the various test runs. $D P$ is lower under air combustion compared to oxyfuel combustion. A similar behavior was observed by Fryda et al. [22] for different coals and coal/biomass blends and by Yu et al. [23] for three coals of different ranks. The reasons for the increased deposition propensity under oxyfuel are discussed in the next paragraphs. Possible parameters affecting the deposition propen sity under oxyfuel are (a) ash dependent, namely, unburnt car bon in ash, ash particle size differences, carbonation under high $\mathrm{CO}_{2}$, ash composition variations, and (b) flue gas dependent, namely, physical gas properties/altered flow fields, gas density variations, local temperature peaks due to higher local $\mathrm{O}_{2}$ concen trations. Each of these identified parameters is addressed separately.

Correlating the DP of the two coals shown in Fig. 5 under the same conditions and the fouling indices presented in Table 2, these indicators seem to be in agreement: the lignite is expected to have a higher fouling propensity as it presents higher values of the foul ing index and the ratio of basic to acidic oxides.

There seems to be a discrepancy however, between the results shown in Figs. 4 and 5. Fig. 5 shows a higher deposition propensi ties of lignite compared to the Russian coal under both oxyfuel and air conditions. However, in Fig. 4 we observe that the lignite shows lower fouling factors than the Russian coal and the difference is even larger by changing combustion environment. The fouling fac tor depends on the deposit layer thickness, but also on its thermal conductivity. As explained in previous section, the effective ther mal conductivity varies with the deposit physical structure. Rezaei et al. [32] measured the thermal conductivity of unsintered ash samples concluding that in general, thermal conductivity increases with decreasing porosity and increasing particle size. According to Zbogar et al. [31] the thermal conductivity of a fused deposit is higher than of a particulate structured deposit. The initial stages

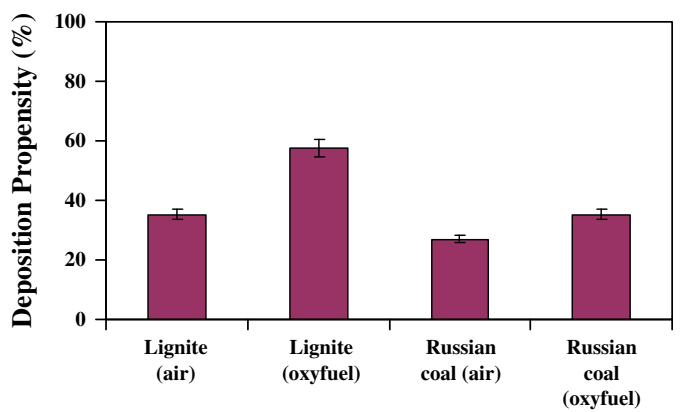

Fig. 5. Deposition propensity for the lignite and the Russian coal under air and oxyfuel combustion conditions.
Table 3

Carbon-in-ash and flue gas composition for the test cases.

\begin{tabular}{lll}
\hline Fuel & $\begin{array}{l}\text { Carbon-in-ash }(\mathrm{w} / \mathrm{w} \%, \text { dry }) \\
\text { Deposited/filter }\end{array}$ & $\begin{array}{l}\text { Flue gas at the exit }\left(\mathrm{CO}_{2} \% /\right. \\
\left.\mathrm{O}_{2} \% / \mathrm{CO} \mathrm{ppm}\right)\end{array}$ \\
\hline $\begin{array}{c}\text { Russian coal } \\
\text { (air) }\end{array}$ & $1.75 / 1.07$ & $10 / 3.0 / 14$ \\
$\begin{array}{c}\text { Russian coal } \\
\text { (oxyfuel) }\end{array}$ & $2.57 / 0.8$ & $87 / 2.5 / 22$ \\
$\begin{array}{l}\text { Lignite (air) } \\
\text { Lignite } \\
\text { (oxyfuel) }\end{array}$ & $0.26 / 0.12$ & $10 / 3.4 /-$ \\
& $0.12 /<0.10$ & $86 / 3.9 /-$ \\
\hline
\end{tabular}

of sintering are accompanied by an increase in the deposit thermal conductivity while subsequent sintering continues to densify the deposit, but has little effect on the deposit thermal conductivity.

\subsubsection{Carbon in ash}

The carbon in ash in the samples was measured, confirming that the higher deposition of the oxyfuel samples was not due to unburnt fuel particles that might be present in the deposits. Car bon in ash levels are shown in Table 3. If the carbon in ash level is high, it may indicate a higher deposition ratio due to carbon deposited. However at some cases higher carbon in ash was ob served in the air cases and some in the oxyfuel cases, not affecting the systematic deposition behavior. Furthermore, during the tests we also monitored the $\mathrm{CO}_{2}, \mathrm{CO}$ and $\mathrm{O}_{2}$ levels in the flue gas (Table 3 ). The low levels of $\mathrm{CO}$ indicate satisfactory combustion, not load ing the deposited ash with carbon particles.

\subsubsection{Particle size distribution}

The ash deposition mechanisms include inertial impaction (impaction and sticking), thermophoresis, condensation and chem ical reaction [33]. The size of ash particles is expected to influence the deposition behavior by influencing directly the impaction of particles on the boiler surface. Inertial impaction is prevailing in reactors as the present one. The deposits were found predomi nantly on the wind side of the deposition probe tube, placed in cross flow, proving the collision of particles on the front area. There was no deposition built up on the sides of the probe or on the lee side of the probe, except of a thin layer of fine ash at the sides. This indicates the presence of other ash deposition mechanisms on our sampling rig, less dominant than inertial impaction, e.g. thermophoresis.

Particles depositing on a surface by inertial impaction have suf ficient inertia to traverse the gas streamlines and impact on the surface. The impaction efficiency is a function of the Stokes num ber [33], which is a ratio of inertial to drag forces. The Stokes num ber is defined as

St $\frac{\rho_{p} d_{p}^{2} U_{p}}{9 \mu_{g} d_{c}}$

where $\rho_{p}$ is the particle density, $d_{p}$ is the particle diameter, $U_{p}$ is the particle velocity, $\mu_{\mathrm{g}}$ is the gas viscosity and $d_{c}$ is the tube diameter. Since St depends on the square of the particle diameter, larger par ticles will collide on the probe (tube) while very small particles tend to follow the gas flow around the tube and will not collide. The St depends also on the gas viscosity, which is slightly higher for the carbon dioxide $\left(5.6 \times 10^{5} \mathrm{~kg} / \mathrm{m} \mathrm{s}\right.$ at $\left.1400^{\circ} \mathrm{C}\right)$ than for the nitrogen $\left(5.3 \times 10^{5} \mathrm{~kg} / \mathrm{m} \mathrm{s}\right.$ at $\left.1400^{\circ} \mathrm{C}\right)$. The higher viscosity of the gas pres ent under oxyfuel conditions would lead to a maximum decrease of the St number of around $4 \%$, what has a limited effect on the impac tion efficiency value. The particle capture efficiency describes the propensity of the impacting particles to stay on the surface once they impact, and mainly depends on particle composition [34]. 


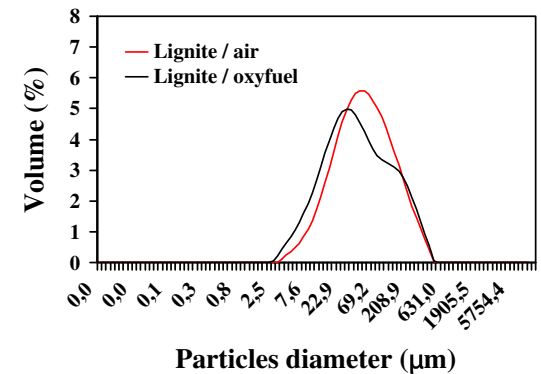

(a) Lignite

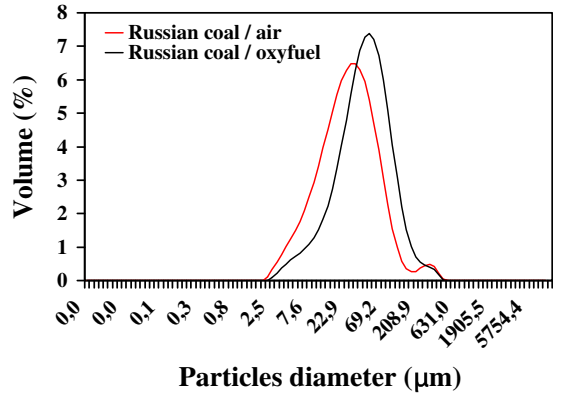

(b) Russian coal

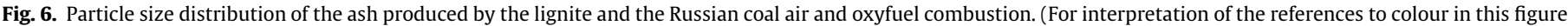
legend, the reader is referred to the web version of this article.)

Fig. 6 shows typical particle size distribution measurements of the fuels' ashes produced under air and oxyfuel conditions.

It can be seen that the particle size distribution of the Russian coal oxy fired ash seems to be shifted to a larger size, justifying the higher deposition propensities and fouling factors observed in comparison with air combustion. However, this trend was not verified for the lignite, where ashes collected under air and oxyfuel conditions present similar particle size distributions, less narrow than those of the Russian coal. Despite the temperature profiles in the two combustion conditions (Fig. 2) being very similar, by matching the combustion gas composition (methane and oxidant) through the burner in order to have similar flame temperatures, the temperature is slightly higher in the oxyfuel case along a certain region close to the flame due to the differ ent heat transfer behavior. These higher local gas temperatures measured in oxyfuel combustion may cause particle ash melt and agglomeration. Nevertheless, the differences in particle size distributions between the two environments are not significant enough to claim that this is the determining parameter respon sible for the higher deposition observed under oxyfuel combustion.

A possible explanation, which was not studied further in our work though, is that the different char combustion temperatures could influence certain mineral phase transformations. For exam ple, the rate of release of $\mathrm{CO}_{2}$ from carbonates present in the ash is mitigated by the high $\mathrm{CO}_{2}$ partial pressures of oxyfuel combus tion. The release of $\mathrm{CO}_{2}$ is thus probably slower under oxyfuel con ditions and starts at higher temperatures. This delay in $\mathrm{CO}_{2}$ release from carbonates in the ash may impact the ash particle size as well by increasing the porosity of the ash particles, which can also ex plain the higher heat transfer resistance (higher fouling factor), ob served in the oxyfuel cases.

\subsubsection{Ash crystallographic (XRD) analyses}

In order to conclude on the effect of increased $\mathrm{CO}_{2}$ partial pres sure on phase changes, $\mathrm{X}$ ray diffraction XRD (metallographic anal yses) were carried out and commented upon. The advantage of the XRD technique is the detection of occurrence and degree of crystal linity of forming major and minor crystalline phases (quartz, mull ite, magnetite, hematite, feldspars, anhydrite, clay minerals, calcite, cristobalite, and others) independent from their size. This is an advantage for the finely dispersed fly ashes. Furthermore, some information for the non crystalline or poorly crystallized phases can also be obtained.

The measurements took place at room temperature in a range of $1070^{\circ} 2$ theta. The expected mineral phases are shown in Table 4.

The intensity of crystalline and glass phases was compared among the samples, with emphasis on the possible differentiations among air and oxyfuel conditions.

All the samples needed a long measurement time because of the moderate crystalline structure and the minimum presence of most of the minerals, just as already expected.

In Fig. 7 the XRD diffractograms patterns of the deposit and fil ter ash samples are shown, while in Fig. 8 the diffractograms of the lignite and Russian coal samples are shown as reference. There is some glass phase in all the samples. It is possible that some more phases are present but cannot be seen because they are amorphous or less in quantity than the prevailing $\mathrm{Si} / \mathrm{Al}$ containing phases.

At the first glance there does not seem to be any variation among the mineral phases of the samples under the various com bustion conditions. Moreover, amorphous phase was detected, and this is also probably the reason for the lack of precision in the re sults, with the peaks overlapping. The aluminosilicate peaks were so intensive that they covered any variations in the other minerals peaks, especially the carbonates and iron containing phases. Sheng

Table 4

Mineral phases expected and found in the coals and ash samples.

\begin{tabular}{|c|c|c|c|}
\hline \multicolumn{2}{|l|}{ Coal ash } & \multicolumn{2}{|l|}{ Ash samples } \\
\hline Expected & Found & Expected & Found \\
\hline Quartz $\left(\mathrm{SiO}_{2}\right)$ & $\sqrt{ }$ & Quartz $\left(\mathrm{SiO}_{2}\right)$ & $\sqrt{ }$ \\
\hline Anorthite, ordered $\left(\mathrm{CaAl}_{2} \mathrm{Si}_{2} \mathrm{O}_{8}\right)$ & $\sqrt{ }$ & Mullite $\left(\mathrm{A}_{6}{ }_{6} \mathrm{Si}_{2} \mathrm{O}_{13}\right)$ & $\sqrt{ }$ \\
\hline Kaolinite $\left(\mathrm{Al}_{2} \mathrm{SiO}_{5}(\mathrm{OH})_{4}\right)$ & $\sqrt{ }$ & Anorthite, ordered $\left(\mathrm{CaAl}_{2} \mathrm{Si}_{2} \mathrm{O}_{8}\right)$ & $\mathrm{X}$ \\
\hline Calcite $\left(\mathrm{CaCO}_{3}\right)$ & $\mathrm{X}$ & Calcite $\left(\mathrm{CaCO}_{3}\right)$ & $\mathrm{X}$ \\
\hline Bassanite $\left(\mathrm{CaSO}_{4} \cdot 0.5 \mathrm{H}_{2} \mathrm{O}\right)$ & $\sqrt{ }$ & Anhydrite $\left(\mathrm{CaSO}_{4}\right)$ & $\sqrt{ }$ \\
\hline Clinochlore $1 \mathrm{MIIb}\left((\mathrm{Mg}, \mathrm{AI}, \mathrm{Fe})_{6}(\mathrm{Si}, \mathrm{Al})_{4} \mathrm{O}_{10}(\mathrm{OH})_{8}\right)$ & $\sqrt{ }$ & Lime $(\mathrm{CaO})$ & $\sqrt{ }$ \\
\hline Pyrite $\left(\mathrm{FeS}_{2}\right)$ & $\mathrm{X}$ & Pyrrhotite without $\mathrm{O}_{2}\left(\mathrm{Fe}_{1}{ }_{x} \mathrm{~S}\right)$ & $\mathrm{X}$ \\
\hline Hematite $\left(\mathrm{Fe}_{2} \mathrm{O}_{3}\right)$ & $?$ & Pyrite $\left(\mathrm{FeS}_{2}\right)$ & $\mathrm{X}$ \\
\hline Siderite $\left(\mathrm{FeCO}_{3}\right)$ & $\sqrt{ }$ & Hematite $\left(\mathrm{Fe}_{2} \mathrm{O}_{3}\right)$ & $\sqrt{ }$ \\
\hline Dolomite $\left(\mathrm{CaMg}\left(\mathrm{CO}_{3}\right)_{2}\right)$ & & Magnetite $\left(\mathrm{Fe}^{2+} \mathrm{Fe}^{3+} \mathrm{O}_{4}\right.$ or $\left.\mathrm{Fe}_{3} \mathrm{O}_{4}\right)$ & $?$ \\
\hline \multirow[t]{2}{*}{ Magnetite $\left(\left(\mathrm{Fe}_{2} \mathrm{Fe}_{2+3}\right) \mathrm{O}_{4}\right.$ or $\left.\mathrm{Fe}_{3} \mathrm{O}_{4}\right)$} & $\sqrt{ }$ & Magnesite $\left(\mathrm{MgCO}_{3}\right)$ & $\mathrm{X}$ \\
\hline & & Portlandite $\left(\mathrm{Ca}(\mathrm{OH})_{2}\right)$ & $\mathrm{X}$ \\
\hline
\end{tabular}




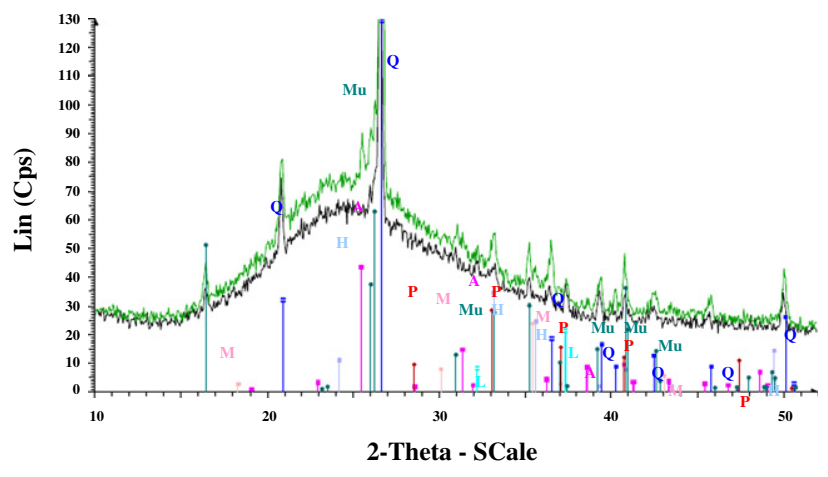

(a) Filter ash (black line) and deposited ash (green line) from lignite under air combustion $\mathbf{Q}=$ Quartz $\mathbf{A}=$ Anhydrite $\mathbb{H}=$ Hematite $\mathbb{L}=$ Lime $\quad \mathbf{M}=$ Magnetite $\mathbf{M u}=$ Mullite $\mathbf{P}=$ Pyrite

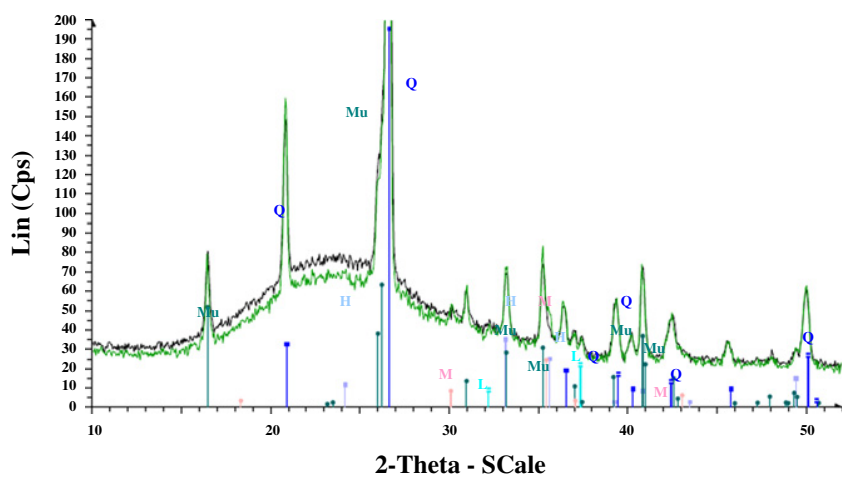

(c) Filter ash (black line) and deposited ash (green

line) from Russian coal under air combustion

Q = Quartz $\quad \mathbf{A}=$ Anhydrite $\quad \mathrm{H}=$ Hematite $\quad \mathrm{L}=$ Lime $\quad \mathrm{M}=$

Magnetite $\mathbf{M u}=$ Mullite $\mathbf{P}=$ Pyrite

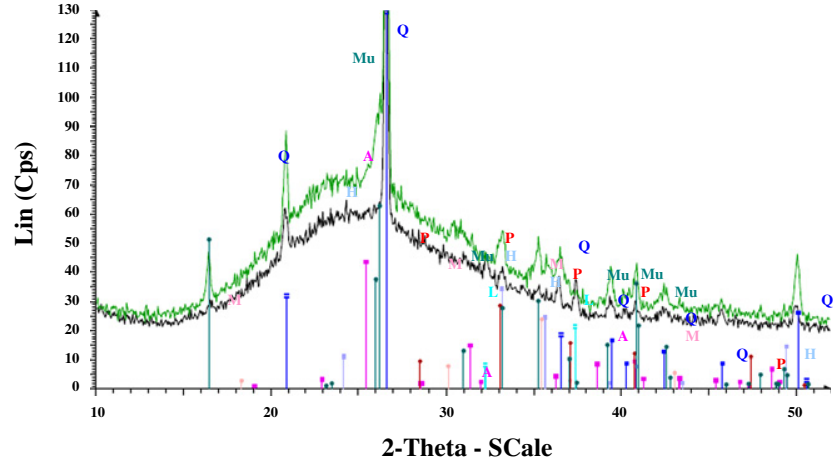

(b) Filter ash (black line) and deposited ash (green line) from lignite under oxyfuel combustion

$\mathbf{Q}=$ Quartz $\mathbf{A}=$ Anhydrite $\mathbb{H}=$ Hematite $\mathbb{L}=$ Lime $\quad \mathbb{M}=$

Magnetite $\mathbf{M u}=$ Mullite $\mathbf{P}=$ Pyrite

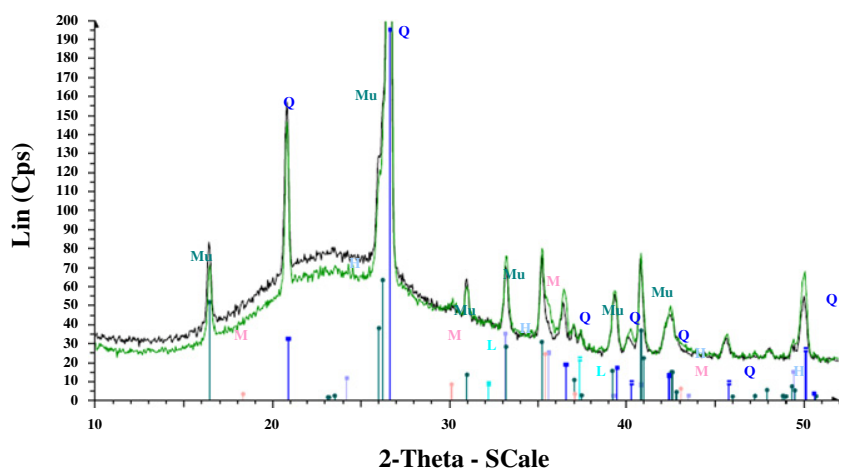

(d) Filter ash (black line) and deposited ash (green line)

from Russian coal under oxyfuel combustion

$\mathbf{Q}=$ Quartz $\mathbf{A}=$ Anhydrite $\mathrm{H}=$ Hematite $\mathbf{L}=$ Lime $\quad \mathbf{M}=$

Magnetite $\mathbf{M u}=$ Mullite $\mathbf{P}=$ Pyrite

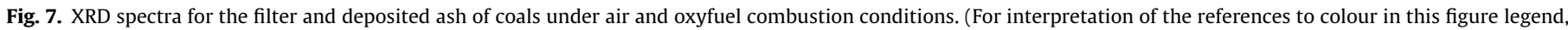
the reader is referred to the web version of this article.)

and $\mathrm{Li}$ [19] also reported similar spectra of the ash from $\mathrm{O}_{2} / \mathrm{CO}_{2}$ and air combustion. They did not observe significant differences in the main crystalline phases and the differences in the relative amounts of the mineral phases were attributed to the difference in char combustion temperatures, as they compared the combustion of different coals in air and in $\mathrm{O}_{2} / \mathrm{CO}_{2}$ but at the same oxygen concentration.

A major conclusion is that in the current presented tests no variations in the phases were clearly observed between air and oxyfuel tests. Of course variations were observed among the ash samples; however these variations are not due to the combustion environment, but due to the different fuel origin. A few comments on the phase transformations are given here.

For the case of lignite, quartz $\left(\mathrm{SiO}_{2}\right)$ remains in the ash in both cases. Anorthite ( $\mathrm{Ca} \mathrm{Al} \mathrm{Si}$ ) and kaolinite ( $\mathrm{Si} \mathrm{Al}$ ) are probably transforming to mullite ( $\mathrm{Si} \mathrm{Al}$ ) and quartz, while the Ca content is found in lime $(\mathrm{CaO})$ and ahydrite $\left(\mathrm{CaSO}_{4}\right)$. However anhydrite could be the direct water removal from the phase bassanite $(\mathrm{Ca}$ $\mathrm{SO}_{4} 0.5 \mathrm{H}_{2} \mathrm{O}$ ). For the lignite case, bassanite is also the only phase that contains the element of $\mathrm{S}$. Fe is contained in the phases of sid erite $\left(\mathrm{FeCO}_{3}\right)$, clinochlore $(\mathrm{Mg} \mathrm{Al} \mathrm{Fe} \mathrm{Si} \mathrm{Al})$ and magnetite $\left(\mathrm{Fe}_{3} \mathrm{O}_{4}\right)$. Magnetite is also found in the ashes of both combustion conditions, but the elements mainly combine into hematite $\left(\mathrm{Fe}_{2} \mathrm{O}_{3}\right)$.

In the case of Russian coal, quartz $\left(\mathrm{SiO}_{2}\right)$ remains in the ash in both cases. Anorthite ( $\mathrm{Ca} \mathrm{Al} \mathrm{Si}$ ) and kaolinite ( $\mathrm{Si} \mathrm{Al}$ ) are probably transforming to mullite ( $\mathrm{Si} \mathrm{Al}$ ) and quartz, while the $\mathrm{Ca}$ content initially bound in dolomite $\left(\mathrm{CaMg}\left(\mathrm{CO}_{2}\right)_{3}\right)$, anorthite and kaolinite is transformed into lime $(\mathrm{CaO})$. Fe is contained in the phase of sid erite $\left(\mathrm{FeCO}_{3}\right)$.

Siderite, present in both coals, is probably transforming into magnetite and hematite $\left(\mathrm{Fe}_{2} \mathrm{O}_{3}\right)$ releasing $\mathrm{CO}_{2}$. The absence of pyr ite in the two coals seems to exclude the formation of Fe containing glass in the produced ashes due to the intermediate oxidation products. The absence of $S$ in the residual ash, as shown by the ICP analysis, indicates the release of $S$ into the flue gas instead of being present in solid mineral phases or glass. Another remark is that hematite $\left(\mathrm{Fe}_{2} \mathrm{O}_{3}\right)$ was only present in the sensor ash samples and not in the filter ash. The same goes for anhydrite $\left(\mathrm{CaSO}_{4}\right)$, it was only present in the sensor ash and only in the lignite case. Magnetite was present in very small amounts in the sensor ashes, while as mentioned the signal of pyrite was very weak and only present in the sensor ash of the oxyfuel case for lignite. The alumi nosilicate peaks are probably too high to allow observations on the transformation of iron and calcium containing phases and carbon ates. Other researchers [19,27] have performed detailed tests on the transformation of iron containing phases and conclude that un der oxyfuel conditions the iron containing phases (pyrite) can lead to the formation of low melting point FeO FeS though pyrrhotite oxidation. This could partly explain the higher deposition propen sity of the fuels under oxyfuel conditions, while the temperatures 


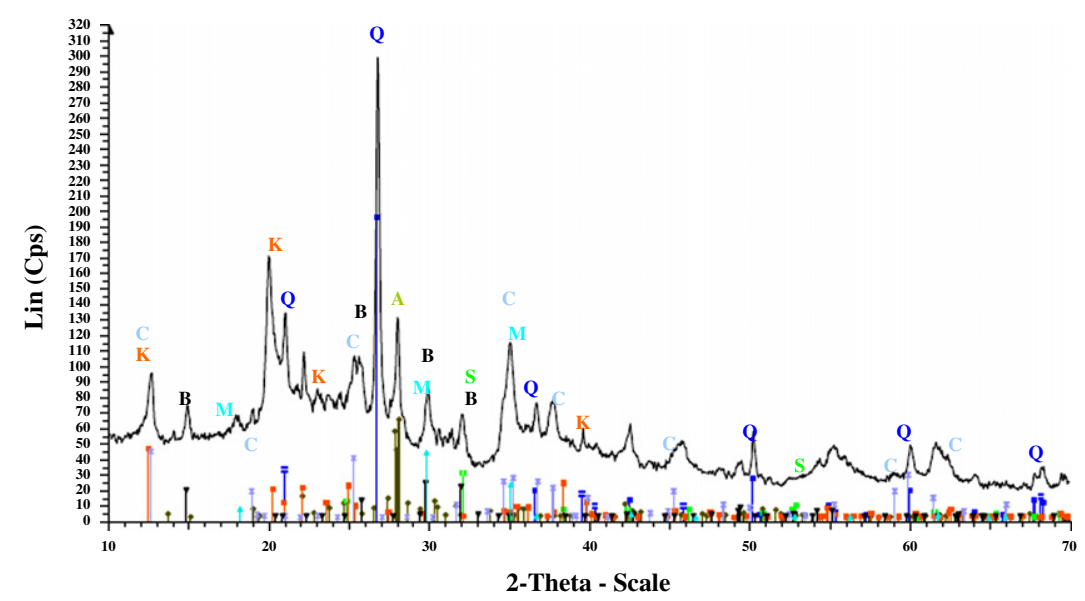

(a) Lignite

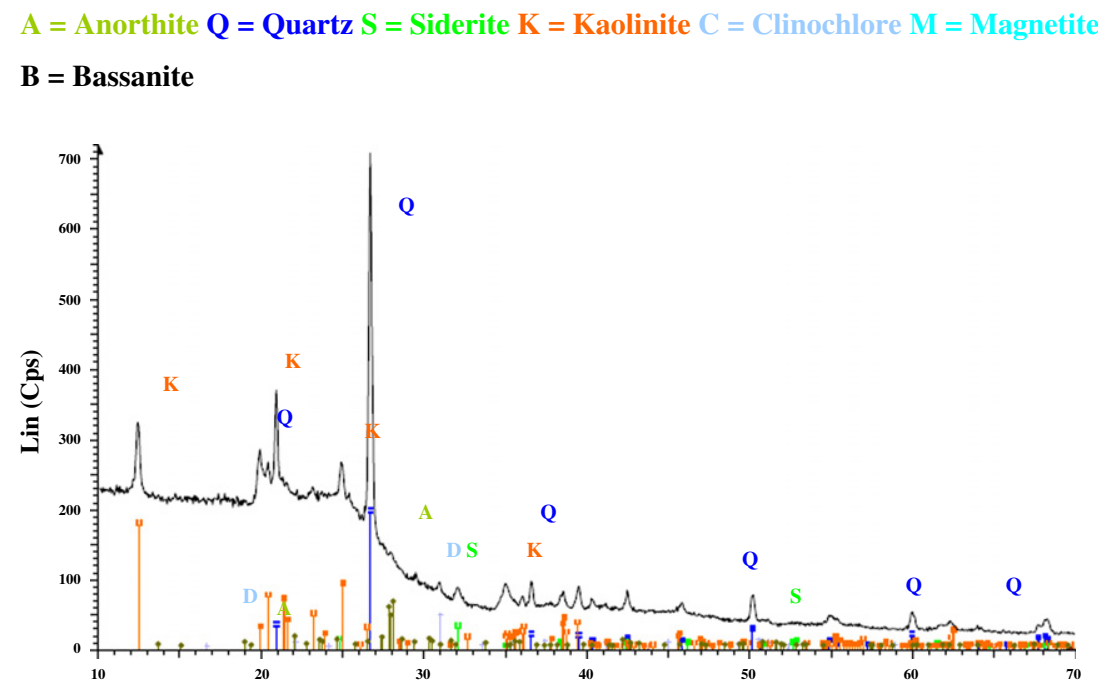

(b) Russian coal

$\mathbf{A}=$ Anorthite $\mathbf{Q}=$ Quartz $\mathbf{S}=$ Siderite $\mathbf{K}=$ Kaolinite $\mathbb{D}=$ Dolomite

Fig. 8. Lignite and Russian coal diffractograms.

and the fuels are the same; however this is strongly depending on the fuel composition itself.

\subsubsection{Chemical composition of ash under air and oxyfuel combustion}

The behavior and distribution of the ash elements was defined and quantified by performing a mass balance including the weight and inorganic composition of the fuels and ash samples obtained from (1) the deposited ash, collected from the horizontal probe, (2) the fly ash, obtained from the filter, which contains the ash that was not deposited on the probe and (3) a batch of non separated ash, collected in the tests done without the horizontal probe.

The results of the elemental composition of the different ash samples are presented using the enrichment factor $E F$, which de scribes the relative enrichment of an element in the sampled ash relative to its concentration in the fuel ash. The enrichment factor $E F$ is defined as

EF $\frac{X_{\text {sample ash }, i}}{X_{\text {fuel ash }, i}}$

where $X_{\text {sample ash }, i}$ is the mass fraction of the element $i$ (expressed as oxide) in either the deposit, the filter or the batch of non separated ash sample and $X_{\text {fuel ash }, i}$ is the mass fraction of the element $i$ (ex pressed as oxide) in the initial ash of the fuel prior to combustion.
The results for the various test cases are given in Figs. 9 and 10, and will be commented upon in the following paragraph.

In Fig. 9 the enrichment factor for most elements does not seem to change between air and oxyfuel conditions. Its fluctuation is due to the fuel origin and not the combustion conditions. Fe and spe cially Ca show smaller EF in the oxyfuel ashes for the two coals. $\mathrm{Cl}$ and $\mathrm{S}$ were at the detection limit; therefore we conclude that there was practically no $\mathrm{S}$ and $\mathrm{Cl}$ in the ash samples. In Fig. 10 the enrichment factors for the sensor and filter ash are shown separately.

It can be observed that the lignite ash collected from the depo sition probe is slightly depleted in potassium and sodium, while the filter ash is slightly enriched, as also observed by other inves tigators [35]. This indicates that a small amount of potassium en ters the gas phase, likely in chloride association (as $\mathrm{KCl}$ ), preventing it from facile deposition [36]. The released $\mathrm{KCl}$ can then condense, but this requires relatively much time, large surface and a low temperature. This is clearly illustrated in the LCS facility, where besides a thin white layer of condensed material observed at the sides and the lee surface of the probe, $\mathrm{K}$ rich deposits may form on cold surfaces also after the filter, in the critical capillary part of the sampling train membrane pump. However this deple tion is not significant as the tested fuels have very low chlorine 


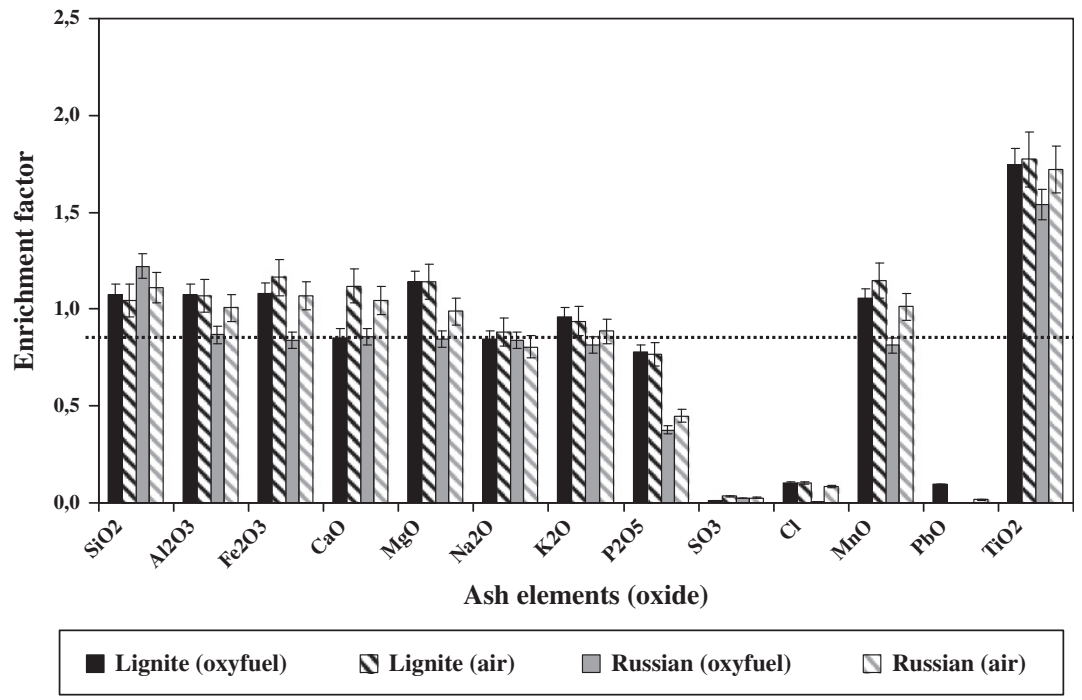

Fig. 9. Enrichment factors of the batch of non-separated ash for the lignite and the Russian coal under air and oxyfuel combustion conditions.

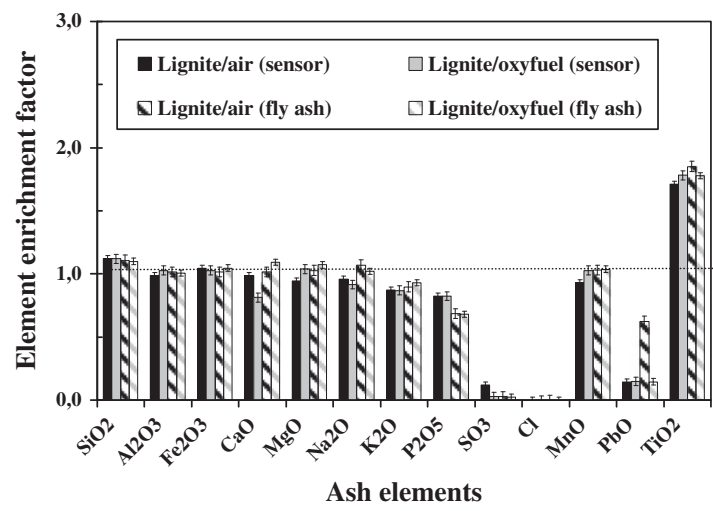

(a) Lignite

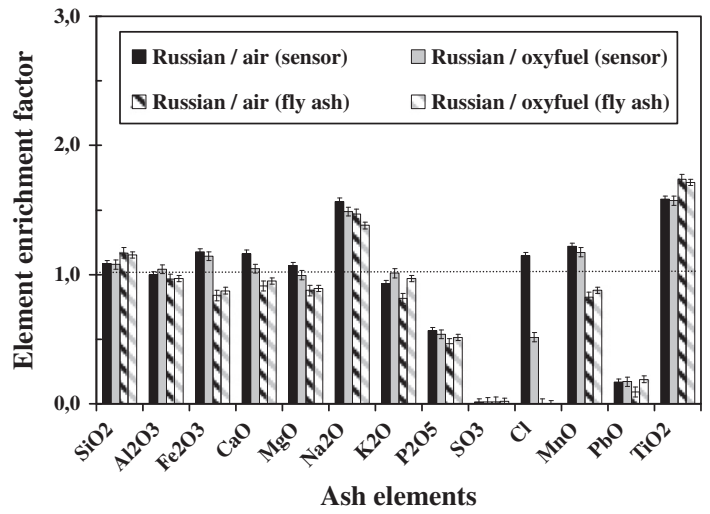

(b) Russian coal

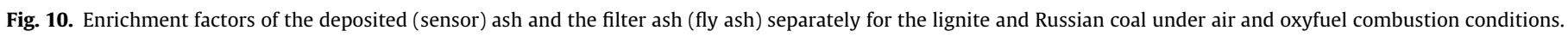

content, and alkalis seem to mainly remain in the ash instead of entering the gas phase ( $E F$ about 1 ).

$\mathrm{S}$ is depleted in both the deposit as well as the filter ash. Most of the potassium and sodium in the deposit is expected to form alkali aluminosilicates rather than remain as free sulfur species (sulfates as well as sulfites and sulfides). The alkalis lower the melting point of silica aluminum based materials, resulting in more sticky parti cle surfaces and thus increasing the probability that particles that strike the deposits or probe will stick.

Phosphorus EF values are similar for the two combustion condi tions, with values lower than 1 .

The sensor ash calcium $E F$ is lower in the oxyfuel case, as also observed for the batch of non separated ash. The other elements show an $E F \sim 1$.

The main conclusion here is that a clear effect of the combus tion environment on the $E F$ results is not observed for the coals studied. We did not study the submicron ash behavior however. The bulk fly ash composition varies from submicron particles as fly ash typically is composed of the oxides (with some condensate salts) while submicron particles are for a large part a condensate of inorganic salts released under combustion. During oxyfuel com bustion, the partial pressures of the flue gas components are al tered. As the vaporization phenomena during combustion are also driven by partial pressure, the amount of condensable salts
( $\mathrm{K}, \mathrm{Na}$, $\mathrm{Ca}$ with $\mathrm{Cl} / \mathrm{S}$ and $\mathrm{OH} / \mathrm{CO}_{3}$ ) that are prone to condensate later on and form submicron particles could vary as well but this was not further studied in this work.

\section{Conclusions}

The observed ash deposition behavior of Russian coal and lig nite under air and oxyfuel combustion conditions showed varia tions. In specific, the fouling factor (the resistance to heat transfer) was higher for the oxyfuel cases, while the deposition propensities were also higher for the two coals under oxyfuel con ditions. Based on these observations, the parameters that affect the ash deposition behavior of fuels are analyzed in an attempt to ex plain the differences observed under air and oxyfuel combustion. First, the particle size distribution of the collected ash was mea sured, the particle size shifting for the Russian coal to larger sizes in the oxyfuel case. The reason for this can be locally increased char combustion temperatures that can lead to local melt formation, ash droplet formation and agglomeration of small particles. How ever, the lignite ash that presents similar particle size distributions for both combustion environments does not confirmed this ten dency and therefore conclusions based on this observations are not decisive. Another possible effect could be the release of $\mathrm{CO}_{2}$ 
from the carbonates that occurs at different rates in air and oxyfuel because of increased $\mathrm{CO}_{2}$ partial pressures that directly influence the decarbonization ratio. A different rate of this phenomenon may affect the char and ash size as well as the density and porosity of the ash, however, the char and ash morphology was not further investigated. Further on, the carbon in ash was measured. No in crease in unburnt char levels was observed in the oxyfuel case, that could artificially increase the deposited ash. The crystallographic composition of the ashes could not indicate some strong variations in the phases formed (e.g. iron containing phases) that would ex plain a serious deposition behavior deviation in the two conditions. The elemental ash composition given from the ICP analysis did not show significant differences related to the combustion environ ment, neither in the filter or deposited ash particles nor in the bulk ash composition.

As a further step, the differences in the flue gas properties be tween air combustion and oxyfuel combustion are considered as the $\mathrm{CO}_{2}$ is denser and has a higher viscosity, which leads to changes in the flow field (velocities, particle trajectory). All the above changes together with the ash particle size shift may play a role in the observed ash deposition phenomena. These effects will be further investigated in a future work, by carrying out CFD numerical simulations of the ash particle deposition in the LCS un der air and oxyfuel environments.

\section{Acknowledgments}

The work presented was financially supported by the RFCS pro jects BOFCOM and ECOSCRUB, the Dutch National project CATO2, and the Dutch National program EOS LT, Consortium Biomass Co firing. The fine work of Peter Heere in operating the reactor is highly acknowledged.

\section{References}

[1] Herzog HJ, Drake EM. Carbon dioxide recovery and disposal from large energy systems. Annu Rev Energy Environ 1996;21:145-66.

[2] Jordal K, Anheden M, Yan J, Strömberg L. Oxyfuel combustion for coal-fired power generation with $\mathrm{CO}_{2}$ capture - opportunities and challenges. Greenhouse Gas Control Technol 2005;7:201-9.

[3] Andersson $\mathrm{K}$, Johnsson F. Process evaluation of an $865 \mathrm{MW}_{\mathrm{e}}$ lignite-fired $\mathrm{O}_{2} / \mathrm{CO}_{2}$ power plant. Energy Convers Manage 2006;47:3487-98.

[4] Buhre BJP, Elliott LK, Sheng CD, Gupta RP, Wall TF. Oxyfuel combustion technology for coal-fired power generation. Prog Energy Combust Sci 2005;31:283-307.

[5] Tan Y, Croiset E, Douglas MA, Thambimuthu KV. Combustion characteristics of coal in a mixture of oxygen and recycled flue gas. Fuel 2006;85:507-12.

[6] Gibbins J, Chalmers H. Carbon capture and storage. Energy Policy 2008;36:4317-22

[7] Wall TF. Combustion processes for carbon capture. Proc Combust Inst 2007;31:31-47.

[8] EU Demonstration Programme for $\mathrm{CO}_{2}$ Capture and Storage (CCS), European Technology Platform for Zero Emission Fossil Fuel Power Plants (ZEP). $<$ http://www.zero-emissionplatform.eu/website/library/index.html\#etpzeppublications>

[9] Wall TF, Liu Y, Spero C, Elliott L, Khare S, Rathnam R, et al. An overview on oxyfuel coal combustion-state of the art research and technology development. Chem Eng Res Des 2009;87:1003-16.
[10] Kiga T, Takano S, Kimura N, Omata K, Okawa M, Mori T, et al. Characteristics of pulverized-coal combustion in the system of oxygen/recycled flue gas combustion. Energy Convers Manage 1997;38:S129-34.

[11] Molina A, Shaddix CR. Ignition and devolatilization of pulverized bituminous coal particles during oxygen/carbon dioxide coal combustion. Proc Combust Inst 2007;31:1905-12.

[12] Liu H, Zailani R, Gibbs BM. Comparisons of pulverized coal combustion in air and in mixtures of $\mathrm{O}_{2} / \mathrm{CO}_{2}$. Fuel 2005;84:833-40.

[13] Murphy JJ, Shaddix CR. Combustion kinetics of coal chars in oxygen-enriched environments. Combust Flame 2006;144:710-29.

[14] Toftegaard MB, Brix J, Peter AJ, Glarborg P, Jensen AD. Oxy-fuel combustion of solid fuels. Prog Energy Combust Sci 2010;36:581-625.

[15] Sheng C, Li Y, Liu X, Yao H, Xu M. Ash particle formation during $\mathrm{O}_{2} / \mathrm{CO}_{2}$ combustion of pulverized coals. Fuel Process Technol 2007;88:1021-8.

[16] Croiset E, Thambimuthu $\mathrm{KV} . \mathrm{NO}_{x}$ and $\mathrm{SO}_{2}$ emission from $\mathrm{O}_{2} / \mathrm{CO}_{2}$ recycled coal combustion. Fuel 2001;80:2117-21.

[17] Okazaki K, Ando T. $\mathrm{NO}_{x}$ reduction mechanism in coal combustion with recycled $\mathrm{CO}_{2}$. Energy 1997;22:207-15.

[18] $\mathrm{Hu} \mathrm{YQ}$ Kobayashi $\mathrm{N}$, Hasatani $\mathrm{M}$. The reduction of recycled- $\mathrm{NO}_{x}$ in coal combustion with $\mathrm{O}_{2} /$ recycled flue gas under low recycling ratio. Fuel 2001;80:1851-5

[19] Sheng C, Li Y. Experimental study of ash formation during pulverized coal combustion in $\mathrm{O}_{2} / \mathrm{CO}_{2}$ mixtures. Fuel 2008;87:1297-305.

[20] Sheng C, Lu Y, Gao X, Yao H. Fine ash formation during pulverized coal combustion - a comparison of $\mathrm{O}_{2} / \mathrm{CO}_{2}$ combustion versus air combustion. Energy Fuels 2007;21:435-40.

[21] Suriyawong A, Gamble M, Lee MH, Axelbaum R, Biswas P. Submicrometer particle formation and mercury speciation under oxygen-carbon dioxide coal combustion. Energy Fuels 2006;20:2357-63.

[22] Fryda L, Sobrino C, Cieplik M, van de Kamp WL. Study on ash deposition under oxyfuel combustion of coal/biomass blends. Fuel 2010;89:1889-902.

[23] Yu D, Morris WJ, Erickson R, Wendt JOL, Fry A, Senior CL. Ash and deposit formation from oxy-coal combustion in a $100 \mathrm{~kW}$ test furnace. Int J Greenhouse Gas Control, doi:10 1016/j ijggc 201104003

[24] Krishnamoorthy G, Veranth JM. Computational modeling of $\mathrm{CO} / \mathrm{CO}_{2}$ ratio inside single char particles during pulverized coal combustion. Energy Fuels 2003;17:1367-71.

[25] Hindiyarti L, Frandsen F, Livbjerg H, Glarborg O, Marshall P. An exploratory study of alkali sulfate aerosols formation during biomass combustion. Fuel 2008;87:1591-600.

[26] Nelson PF. Trace metal emissions in fine particles from coal combustion. Energy Fuels 2007;21:477-84.

[27] Bhargava SK, Garg A, Subasinghe ND. In situ high-temperature phase transformation studies on pyrite. Fuel 2009;88:988-93.

[28] Mönckert P, Dhungel B, Kull R, Maier J. Impact of combustion conditions on emission formation $\left(\mathrm{SO}_{2}, \mathrm{NO}_{x}\right)$ and fly ash. In: 3rd Workshop of the IEA GHG international oxy-combustion network, Yokohama, Japan; March 5-6, 2008.

[29] Visser HJM. The influence of fuel composition on agglomeration behaviour in fluidised-bed combustion. Report: ECN-C-04-054; 2004.

[30] Wei X, Lopez C, von Puttkamer T, Schnell U, Unterberger S, Hein KRG. Assessment of chlorine-alkali-mineral interactions during co-combustion of coal and straw. Energy Fuels 2002;16:1095-108.

[31] Zbogar A, Frandsen F, Jensen PA, Glarborg P. Shedding of ash deposits. Prog Energy Combust Sci 2009;35:31-56.

[32] Rezaei HR, Gupta RP, Bryant GW, Hart JT, Liu GS, Bailey CW, et al. Thermal conductivity of coal ash and slags and models used. Fuel 2000;79:1697-710.

[33] Baxter LL. Ash deposition during biomass and coal combustion: a mechanistic approach. Biomass Bioenergy 1993;4:85-102.

[34] Lokare SS, Dunaway JD, Moulton D, Rogers D, Tree DR, Baxter LL. Investigation of ash deposition for a suite of biomass fuels and fuel blends. Energy Fuels 2006;20:1008-14.

[35] Nielsen HP, Baxter LL, Sclippa G, Morey C, Frandsen FJ, Dam-Johansen K. Deposition of potassium salts on heat transfer surfaces in straw-fired boilers: a pilot-scale study. Fuel 2000;79:131-9.

[36] Robinson AL, Junker H, Baxter LL. Pilot-scale investigation of the influence of coal-biomass cofiring on ash deposition. Energy Fuels 2002;16:343-55. 